С.В. ЯГЕЛЮК, В.Ф. ДІДУХ, Ю. М. ОНЮХ

Луцьький наџіональний технічний університет

\title{
ОЦІНКА ЯКОСТІ ВОЛОКНА ЗІ СТЕБЕЛ ЛЬОНУ ОЛІЙНОГО, ВИРОЩЕНОГО В УМОВАХ ЗАХІДНОГО ПОЛІССЯ
}

\author{
С.В. ЯГЕЛЮК, В.Ф. ДИДУХ, Ю. М. ОНЮХ \\ Луиякий наџиональний технический университет
}

\section{ОЦЕНКА КАЧЕСТВА ВОЛОКНА ИЗ СТЕБЛЕЙ ЛЬНА МАСЛИЧНОГО, ВЫРОЩЕННОГО В УСЛОВИЯХ ЗАПАДНОГО ПОЛЕСЬЯ}

\author{
S.V. YAHELYUK, V. F. DIDUH, Y. M. ONYUH \\ Lutsk National Technical University
}

\section{THE QUALITY OF OIL FLAX STEAMS FIBER GROWN UNDER THE WESTERN POLYUSYA CONDITIONS EVALUATION}

\section{https://doi.org/10.36910/6775-2310-5283-2018-11-19}

Мета. Визначити комплексний показник якості для волокна зі стебел льону олійного, вирощеного в аграрно кліматичних умовах Західного Полісся.

Методика. Для визначення комплексного показника якості волокна льону олійного використовували аналітичні та розрахункові методи. Значення показників якості отримані експериментально з допомогою сучасних вимірювальних засобів у відповідності до діючих нормативно-технічних документів.

Результати. Комплексне використання льону олійного передбачає застосування волокна, яке можна з нього отримати. На сьогодні встановлені основні фактори, що впливають на формування споживних властивостей волокна льону. В статті розраховані коефіцієнти вагомості для основних показників якості волокна льону. Для визначення вмісту волокна, лінійної щільності, розривного навантаження, масодовжини та кольору використали методи досліджень визначені у стандартах. Досліджувались сорти льону олійного Сонєчни та льону-довгунцю Чарівний, вирощені на дослідних ділянках. Базовими приймалися максимальні значення показників, які встановлені стандартами. Комплексний показник якості волокна льону олійного та волокна льону-довгуния становить відповідно 0,70 та 0, 92. Тому можна зробити висновок, щзо волокно льону олійного, отримане за відповідних кліматичних умов і зібране у встановлені строки придатне для подальшого використання в текстильній та інших галузях промисловості.

Наукова новизна. Розрахований комплексний показник якості для волокна отриманого зі стебел льону олійного, вирощеного в аграрно-кліматичних умовах Західного Полісся.

Практичне значення. Показана можливість комплексного використання льону олійного, вирощеного в аграрно-кліматичних умовах Західного Полісся.

Ключові слова: волокно, льон олійний, показники якості, лінійна щільність, розривне навантаження, масодовжина, колір. 
Постановка проблеми у загальному вигляді та іï зв'язок 3 важливими науковими $\mathbf{i}$ практичними завданнями. Комплексне використання льону олійного передбачає застосування волокна, якість якого формується під впливом природно-кліматичних умов. 3 льону олійного, вирощеного в умовах Західного Полісся можна отримати волокно, придатне для подальшого використання в текстильній та інших галузях промисловості. Проте до сьогодні не визначали комплексні показники якості такого волокна, хоча експерименти по дослідженню одиничних показників вже проводились. Для подальшого ефективного розвитку льонарської галузі є необхідність у визначенні комплексного показника якості волокна льону олійного вирощеного в умовах Західного Полісся.

Аналіз останніх досліджень, у яких започатковано вирішення проблеми. Дослідженню показників споживчих властивостей рослинних волокон присвячено багато наукових праць $[1-3,6]$. Детально вивчені i проаналізовані показники споживчих властивостей льону-довгунцю [4,5]. Встановлені основні закономірності їх формування. Також є дані щодо значень показників якості споживних властивостей волокна льону олійного, в тому числі, вирощеного в аграрно-кліматичних умовах Західного Полісся $[1,6]$.

Цілі статті. Визначити комплексний показник якості для волокна зі стебел льону олійного, вирощеного в аграрно кліматичних умовах Західного Полісся.

Виклад основного матеріалу дослідження 3 повним обгрунтуванням отриманих наукових результатів. Визначення комплексного показника якості льняного волокна проводять в декілька етапів. Спочатку вибирають показники, які характеризують якість. Одиничні показники якості характеризують одну властивість волокна (наприклад, міцність, вологість). Для оцінки якості необхідно звести всі одиничні показники в порівнюваний вигляд, тобто визначити узагальнений показник якості волокна, який повинен якнайповніше відображати корисний ефект від його використання 3 визначеною метою. На другому етапі команда експертів встановлює визначальні показники. Враховують ті показники, які є найбільш значущими для споживача.

Групи експертів використовують, як правило, балову систему оцінювання. Для отримання достовірних результатів проводять опитування в декількох повторюваностях. Для забезпечення необхідного рівня точності достатньо двох-трьох. Експерти визначають коефіцієнти вагомості показників 
якості льняного волокна в частках одиниці. Для оцінки вагомості показників якості льняного волокна використовували п’ятибалову шкалу. Отримані значення використовуються для визначення середнього арифметичного значення балу для кожного показника (А) за формулою:

$$
A=\frac{1}{N} \sum_{j=1}^{N} a_{i j}, i=1 \ldots n
$$

де $\quad n-$ кількість параметрів товару;

$N$ - кількість експертів;

$a_{i j}$ - параметри вагомості i-го показника, що визначені j-м експертом.

Нормовані коефіцієнти вагомості обчислюються за формулою

$$
q_{i}=\frac{\bar{A}}{\sum_{i=}^{n} \bar{A}_{i}}
$$

Згідно раніше проведених досліджень [1, 3, 6] та нормативних документів [7, 8, 9, 10] основними показниками якості льняного волокна $\epsilon$ масодовжина, вміст волокна у тресті, віддільність волокна, вологість, розивне наванаження, лінійна щільність, колір волокна, загальний вихід волокна, вихід довгого волокна. Розрахунки проводились з допомогою програми Microsoft Excel. Результати визначення коефіцієнтів вагомості показані у табл. 1.

Таблиця 1

\section{Підсумкові результати оцінювання вагомості показників якості волокна}

\begin{tabular}{|c|c|c|c|c|c|c|c|c|c|c|c|c|}
\hline Пока & Позначення & E1 & E2 & E3 & E4 & E5 & $\mathrm{q}_{1}$ & $\mathrm{q}_{2}$ & $\mathrm{q}_{3}$ & $\mathrm{q}_{4}$ & $\mathrm{q}_{5}$ & $\begin{array}{c}\text { Середнє } \\
\text { значен- } \\
\text { ня q }\end{array}$ \\
\hline Масо-довж & $\mathrm{P} 1$ & 5 & 5 & 5 & 5 & 5 & 0,17 & 0,19 & 0,17 & 0,18 & 0,19 & 0,18 \\
\hline Вміст волокна у тресті & $\mathrm{P} 2$ & 4 & 4 & 4 & 5 & 4 & 0,14 & 0,15 & 0,14 & 0,18 & 0,15 & 0,15 \\
\hline Відділь-ність волокна & P3 & 2 & 1 & 3 & 3 & 1 & 0,07 & 0,04 & 0,10 & 0,11 & 0,04 & 0,07 \\
\hline Вологість & $\mathrm{P}$ & 3 & 2 & 2 & 2 & 3 & 0,10 & 0,07 & 0,07 & 0,07 & 0,12 & 0,09 \\
\hline Розивне наван-таж & $\mathrm{P5}$ & 5 & 4 & 5 & 4 & 5 & 0,17 & 0,15 & 0,17 & 0,14 & 0,19 & 0,17 \\
\hline Лінійна щільність & P6 & 4 & 5 & 4 & 4 & 4 & 0,14 & 0,19 & 0,14 & 0,14 & 0,15 & 0,15 \\
\hline Колір волокна & P7 & 3 & 3 & 3 & 3 & 2 & 0,32 & 0,11 & 0,10 & 0,11 & 0,08 & 0,14 \\
\hline Загальний вихід волокн & P8 & 2 & 1 & 2 & 1 & 1 & 0,07 & 0,04 & 0,07 & 0,04 & 0,04 & 0,05 \\
\hline Вихід довгого волокна & P9 & 1 & 2 & 1 & 1 & 1 & 0,03 & 0,07 & 0,03 & 0,04 & 0,04 & 0,04 \\
\hline
\end{tabular}
льону

Відповідно до даних в табл. 1 пріоритетними для випадку, що розглядається будуть показники 3 найбільшими коефіцієнтами вагомості. Показниками, що мають коефіцієнт менший 0,1 можна знехтувати. Далі будемо розглядати показники наведені в табл.2 . 
На третьому етапі проводиться вибір методів дослідження для отримання значень обраних показників. Для визначення вмісту волокна, лінійної щільності, розривного навантаження, масодовжини та кольору використали методи досліджень визначені у стандартах $[9,10]$.

Таблиця 2

Показники льоноволокна, відібрані для оцінки якості

\begin{tabular}{|l|c|c|}
\hline \multicolumn{1}{|c|}{ Показник } & Позначення & Коефіцієнт вагомості \\
\hline Вміст волокна у тресті, \% & P2 & 0,15 \\
\hline Лінійна щільність, Текс & P6 & 0,15 \\
\hline Розивне наванаження, даН & P5 & 0,17 \\
\hline Масодовжина, мм & P1 & 0,18 \\
\hline Колір, бал & P7 & 0,14 \\
\hline
\end{tabular}

На четвертому етапі здійснюється оцінка якості льоноволокна. Досліджувались сорти льону олійного Сонєчни та льону-довгунцю Чарівний, вирощені на дослідних ділянках. Вологість становила $12 \%$, відокремлюваність була в межах 4,5-5,0. Стебла вибирались, вилежувались на ділянках до перетворення у тресту і оброблялись в лабораторних умовах.

Для визначення відносних показників використовують бальні шкали. Під час визначення лабораторних і розрахункових показників виконуються дві операції: вимірювальна (або розрахункова) і оціночна.

Комплексний показник якості для оцінки волокна льону, отриманого із стебла льону-олійного та льону довгунця розраховується шляхом зведення окремих показників 3 врахуванням коефіцієнта вагомості для кожного показника.

Базовими приймали максимальні значення показників, які визначені нормативно-технічними документами.

Визначення відносних показників $\left(K_{i}\right)$ волокна льону проводилося за формулою:

$$
K_{i}=\frac{P_{i}}{P_{\text {баз }}},
$$

де $\quad P_{\text {баз }}-$ базове значення $\mathrm{i}-$ го показника;

$P_{i}-$ значення i-го показника. 
Товарознавчий вісник. - 2018. - Випуск 11.

Значення відносних показників якості досліджуваних зразків волокна льону подано в табл. 3.

Таблиця 3

\section{Значення відносних показників якості волокна льону}

\begin{tabular}{|l|c|c|c|c|c|}
\hline \multirow{2}{*}{$\begin{array}{l}\text { Кодоване } \\
\text { значення }\end{array}$} & \multicolumn{2}{|c|}{ Кількісні значення показників } & \multicolumn{2}{|c|}{ Відносні значення показників } \\
\cline { 2 - 5 } & $\begin{array}{c}\text { базові } \\
\text { зачення }\end{array}$ & льон-довгунець & льон олійний & льон-довгунець & льон олійний \\
\hline P2 & 20,10 & 30,50 & 29,63 & 1,52 & 1,47 \\
\hline P6 & 3,90 & 3,90 & 1,60 & 1,00 & 0,41 \\
\hline P5 & 25,80 & 30,40 & 23,70 & 1,18 & 0,92 \\
\hline P1 & 45,00 & 50,00 & 24,20 & 1,11 & 0,54 \\
\hline P7 & 5,00 & 5,00 & 5,00 & 1,00 & 1,00 \\
\hline
\end{tabular}

Комплексний показник якості волокна льону олійного та волокна льонудовгунця (К) розраховували за формулою:

$$
K=\sum_{i=1}^{n} B \Pi i \times \overline{K B i},
$$

де $\quad B П i-$ відносне значення i-го показника;

$\overline{K B i}$ - середнє значення коефіцієнта вагомості і-го показника;

$n$ - кількість оцінюваних показників.

Комплексні показники якості досліджуваних зразків льоноволокна наведені в табл. 4.

На основі даних наведених в табл. 4 можна зробити висновки про придатність волокна, отриманого з стебла льону олійного, для подальшої переробки.

Таблиця 4

Комплексний показник якості досліджуваних зразків (КПЯ)

\begin{tabular}{|l|c|c|c|}
\hline \multirow{2}{*}{ Показник } & \multirow{2}{*}{$\begin{array}{c}\text { Коефіцієнт } \\
\text { вагомості }\end{array}$} & \multicolumn{2}{|c|}{ Відносні значення показників } \\
\cline { 3 - 4 } & 0,15 & 1,52 & льон-довгунець \\
\hline Вміст волокна у тресті, \% & 0,15 & 1,00 & 0,47 \\
\hline Лінійна щільність, Текс & 0,17 & 1,18 & 0,41 \\
\hline Розивне наванаження, даН & 0,18 & 1,11 & 0,54 \\
\hline Масодовжина, мм & 0,14 & 1,00 & 1,00 \\
\hline Колір, бал & & 0,92 & 0,70 \\
\hline$K$ & & & \\
\hline
\end{tabular}

Проте, необхідно зазначити, що стебла льону вибирались на дослідних ділянках, кліматичні умови вирощування і збирання в роки проведення досліджень (2015-2016 р) сприяли отриманню волокна високої якості. Різницю значень комплексного показника якості льону олійного в порівнянні 
3 льоном-довгунцем можна пояснити тим, що базові значення вибирали на основі нормативно-технічних документів, розроблених для оцінки якості льону-довгунця. Насьогодні не має нормативно-технічних документів, що регламентують якість волокна отриманого з стебла льону олійного. Однак 3 урахуванням описаних вище умов, дослідження показали, що волокно льону олійного, отримане зі стебел, вирощених в кліматичних умовах Західного Полісся має високу якість.

Висновки. Отже, можна зробити висновок, що волокно льону олійного, отримане за відповідних кліматичних умов і зібране у встановлені строки придатне для подальшого використання в текстильній та інших галузях промисловості.

\section{Література}

1. Тіхосова Г.А. Розвиток наукових основ технологій первинної переробки волокон льону олійного [Текст] : дис. ... д-ра техн. наук : 05.18.01 / Г. А. Тіхосова; Херсон. нац. техн. ун-т. - Херсон, 2011. - с.387.

2. Калінський Є. О. Удосконалення та автоматизація процесів визначення якісних показників лляного волокна / Є. О. Калінський // Вестник ХНТУ (Технология легкой и пещевой промішленности): зб. наук. ст - Херсон: Херсонський НТУ - 2014 - № 4(51).

3. Бартків Л.Г. Оцінка якості стебел соломи льону олійного різних способів збирання з метою розробки нормативних документів / Л.Г. Бартків, Л.А. Чурсіна, О.О. Горач// Вестник ХНТУ (Технология легкой и пещевой промішленности): зб. наук. ст Херсон: Херсонський НТУ - 2015 - № 4(55) 88-92.

4. Ягелюк С. В. Визначальні показники якості льоносировини / С.В. Ягелюк // Товарознавчий вісник: зб. наук. праць. - Луцьк: Луцький НТУ - 2013. - Вип. 6. С. 153-158

5. Ягелюк С.В. Формування властивостей льняних матеріалів: монографія / С.В. Ягелюк. - Луцьк: Луцький НТУ, 2016. - 144 с.

6. Дідух В.Ф. Показники споживних властивостей волокна льону олійного, вирощеного в умовах Західного Полісся / В.Ф. Дідух, С.В. Ягелюк, Ю.М. Онюх // Сільськогосподарські машини: зб. наук. ст. - Луцьк: Луцький НТУ - 2017 - Вип. 38.

7. ГОСТ-28285-89. Солома льняная. Требования при заготовках; введ. - М.: Изд-во стандартов, 1990. - 22 с.

8. ДСТУ 4149:2003. Треста лляна. Технічні умови. - К.: Держспоживстандарт України, 2004. - 14 с.

9. ДСТУ 4015:2001. Льон тіпаний. Технічні умови. - К.: Держспоживстандарт України, 2001. - 12 с.

10. ДСТУ 4015:2008. Волокно лляне коротке. Технічні умови - К.: Держспоживстандарт України, 2009. - 12 с.

Цель. Определить комплексный показатель качества для волокна, полученного из стеблей льна масличного, выращенного в аграрно климатических условиях Западного Полесья.

Методика. Для определения комплексного показателя качества льняного волокна из стеблей льна масличного использовали аналитические и расчетные методы. Значения показателей качества получень экспериментально $c$ помощью современных 
измерительных средств в соответствии с действующими нормативно-техническими документами.

Результаты. Комплексное использование льна масличного предусматривает применение волокна, которое можно из него получить. На сегодняшний день установлень основные факторы, влияюшие на формирование потребительских свойств льняного волокна. В статье рассчитаны коэффициенты весомости для основных показателей качества льняного волокна. Для определения содержания волокна, линейной плотности, разрывной нагрузки, массодлины и иявета использовали методы исследований, описанные в стандартах. Исследовались сорта льна масличного Сонечны и льна-долгунца Чаривный, выращенные на опытных участках. Базовыми принимались максимальные значения показателей, установленные стандартами. Комплексный показатель качества волокна льна масличного и волокна льна-долгунца составляет соответственно 0,70 и 0,92. Поэтому можно сделать вывод, что волокно из стеблей льна масличного, полученное при соответствуюших климатических условиях и собранное в установленные сроки, пригодно для дальнейшего использования в текстильной и других отраслях промышленности.

Научная новизна. Рассчитан комплексный показатель качества для волокна полученного из стеблей льна масличного, выращенного в аграрно-климатических условиях Западного Полесья.

Практическое значение. Показана возможность комплексного использования льна масличного, выращенного в аграрно-климатических условиях Западного Полесья.

Ключевые слова: волокно, лен масличный, показатели качества, линейная плотность, разрывная нагрузка, массодлина, цивет

Goal. Determine a comprehensive quality index for oil flax stems fiber grown under agrarian climatic West Polissia conditions.

Method. To determine the complex index of oil flax stems fiber the analytical and calculation methods were used. The values of the quality indices are obtained experimentally with the help of modern measuring instruments in accordance with the current normative and technical documents .

Results. The comprehensive use of oil flax involves the use of fiber that can be obtained from it. Up for today, the main factors influencing the formation of consumer properties of linen fibers have been established. The weighting coefficients for the main indicators of linen quality are calculated in the article. The methods of research described in the standards were used to determine the fiber content, linear density, breaking load, mass lenght and colors. Flaxseed varieties of Solnechny and long fibred flax Charivny, grown on experimental sites were studied. The basic values of the indicators set by the standards were taken as the basis. The combined index of oil flax fiber and long fibred-flax fiber is respectively 0.70 and 0.92 . Therefore, it can be concluded that fiber of oil flax obtained in appropriate climatic conditions and collected in due time, is suitable for further use in the textile and other industries.

Scientific novelty. The complex quality index for oil flax fiber grown under the Western Polissya agro-climatic conditions was calculated.

Practical value. The opportunity of the integrated use of oil flax fiber grown under the Western Polissya agro-climatic conditions is shown.

Key words: fiber, oil flax, quality indicators, linear density, breaking load, mass length, color.

Рекомендовано до публікаиії докт.техн.наук, професором Луиького НТУ Байдаковою Л.І. Дата надходження в редакиію 22.02.2018 p. 